\title{
A Pronúncia das Vogais Médias no Português Europeu e no Português Brasileiro: um estudo diacrônico
}

\author{
The pronunciation of the middle vowels in European \\ and Brazilian Portuguese: a diachronic study
}

Geruza de Souza Graebin ${ }^{\star}$

\begin{abstract}
Resumo
Este estudo diacrônico procura entender as continuidades e descontinuidades fonéticas e fonológicas entre o Português Europeu e o Português Brasileiro, tendo como enfoque as vogais médias em posição pretônica. Este artigo enumera, também, possíveis fatores envolvidos nos processos de variação e mudança, levantando pistas para a compreensão das diferentes pronúncias das vogais médias em posição pretônica no solo brasileiro.
\end{abstract}

Palavras-chave: variação linguística; vogais médias pretônicas; Português brasileiro; Português europeu.

Abstract

This diachronic study seeks to understand the continuities and discontinuities between phonetic and phonological European Portuguese and Brazilian Portuguese, with the focus on the mid vowels in pretonic position. This article lists also possible factors involved in the processes of variation and change, raising clues to understanding the different pronunciations of the pretonic mid vowels in Brazilian soil.

Key words: linguistic variation; mid vowels; Brazilian Portuguese; European Portuguese.

${ }^{\star}$ Universidade de Lisboa 
G. S. Graebin

A Pronúncia das

Vogais Médias

no Português

Europeu e

no Português

Brasileiro: um

estudo diacrônico

\section{Introdução}

pronúncia das vogais em posição pretônica apresenta grande variação
no Português Brasileiro (doravante $\mathrm{PB}$ ). Andando pelo Brasil, pode-se
ouvir môchila e muchila, assim também como côração e còração. Podese ouvir, ainda, dèlègacia e dêlêgacia, ou mêlhor, mèthor e milhor. Quais seriam as origens dessas variações? Por que as vogais médias /e/ e /o/ apresentam variação entre a pronúncia média-aberta, média-fechada e alta? Como as diferentes pronúncias estão espalhadas pelo Brasil? Em que medida o Português Europeu (doravante PE) teria um papel relevante nesse fenômeno linguístico?

Para entender a origem e o percurso dessas diferenciadas pronúncias das vogais médias, dados e informações de dialetólogos, historiadores, gramáticos e linguistas são fundamentais. Sabemos que a variação e a mudança não são fenômenos pontuais, mas estão encaixados num processo histórico e social. Por essa razão, desenvolvemos uma pesquisa diacrônica, analisando, primeiramente, o percurso fonético e fonológico do PE e, posteriormente, o do PB. Por fim, procuramos estabelecer relações entre eles, demonstrando que, em vários aspectos, o PB preservou as tendências já encontradas na Europa, tanto no caso do fenômeno da elevação das vogais - o qual tornou-se supradialetal, ou seja, é
Revista Letras,

Curitiba, UfPR, n. 96, pp.104-131, jul./dez. 2017. ISSN 2236-0999 (versão eletrônica) 
encontrado em todo o país em palavras como minino e bunito-, como no caso do fenômeno do abaixamento das pretônicas, restrito a variedades faladas na região Nordeste.

\section{Português europeu}

Uma das primeiras variações atestadas para as vogais médias em posição pretônica surgiu na evolução do latim vulgar para o português. A perda de consoantes intervocálicas do latim desencadeou hiatos, também perdidos posteriormente, como, por exemplo, em

$$
\begin{aligned}
& \text { malum }>\text { ma-o }>\text { mau } \\
& \text { colore }>\text { co-or }>\text { cor }
\end{aligned}
$$

Segundo Teyssier (2004, p. 41-51), até o fim do século XV, essa mudança já havia sido concluída. A pronúncia média-aberta $[\varepsilon]$ e [0] foi utilizada como recurso para marcar a contração dos hiatos em posição pretônica:

$$
\begin{aligned}
& \text { esca-ecer > esqueecer > esquècer } \\
& \text { pré-egar > prègar } \\
& \text { co-orar > còrar }
\end{aligned}
$$

Essa pronúncia também serviu para marcar a queda de consoantes - na fala, não na escrita - em palavras eruditas:

$$
\begin{aligned}
& \text { director > dirètor } \\
& \text { adopção > adòção }
\end{aligned}
$$

De acordo com a pesquisa histórico-gramatical realizada por Silva (1989, p. 58), a gramática de João de Barros de 1540 lista diversos itens lexicais com a vogal /e/ na forma média-aberta: bèsteiros; conjèctura; crèdor; frècheiros; gèrar; gèraçam; gèral; gèraes; gèralmente; prègando; sètada. Tais mudanças ampliaram o sistema das vogais em posição pretônica, igualando-o ao da posição tônica, então com 8 vogais, como mostra o quadro 1 abaixo:

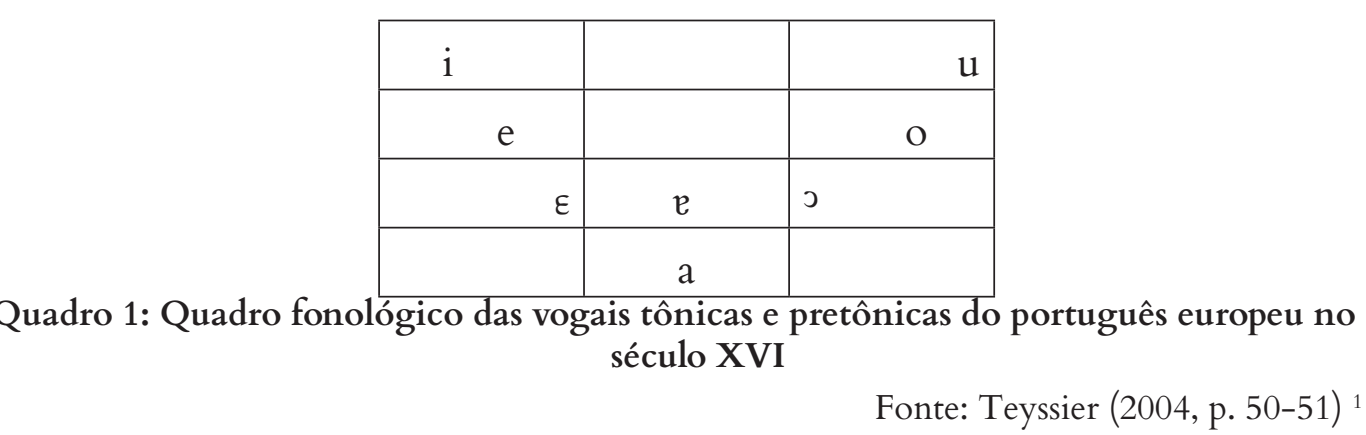

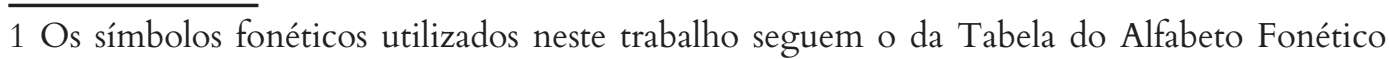
Internacional (IPA). Como os símbolos utilizados por Teyssier (2004) seguem um padrão pouco 
G. S. Graebin

A Pronúncia das

Vogais Médias

no Português

Europeu e

no Português

Brasileiro: um

estudo diacrônico

Nos casos em que houve a perda da consoante intervocálica, mas não a perda do hiato, por serem duas vogais distintas, as vogais médias sofreram elevação (cf. NARO, 1973, p. 54):

$$
\begin{aligned}
& \text { volare }>\text { voar }>\text { vuar } \\
& \text { dolere }>\text { doer }>\text { duer } \\
& \text { venatum }>\text { veado }>\text { viado } \\
& \text { molinum }>\text { moinho }>\text { muinho }
\end{aligned}
$$

Outra alternância na pronúncia das pretônicas foi documentada ainda no século XVI pelos gramáticos: entre a forma média-fechada e a forma alta, ou seja, entre [e i] e [o u]. Provocada geralmente pela assimilação da vogal alta na sílaba seguinte, a elevação da pretônica não era uma regra categórica, mas variável. Assim, havia a coocorrência das formas somir, sumir, conforme a gramática de Fernão de Oliveira, de 1536 (apud NARO, 1973, p. 17) e vistir, vestimenta, vistido; gemer, gimido, conforme a gramática de Duarte Nunez do Lião, de 1576 (apud NARO, 1973, p. 18). A dissimilação também era um fenômeno frequente, e as gramáticas fazem referência à pronúncia com ambas as vogais: médias-fechadas [e], [o] e altas [i], [u]: dizia > dezia; futuro > foturo; instrumento > estormento (TEYSSIER, 2004, p. 74; NARO, 1973, p. 39).

A elevação ocorria para a vogal /e/ em ambiente de sílaba travada por nasal ou /S/ no início da palavra, como em entender; escola (cf. TEYSSIER, 2004, p. 74). Segundo Naro (1973, p. 39), a elevação no contexto nasalizado decorreu de uma confusão dos prefixos na evolução do latim para o português. Para o verbo latino intrare, por exemplo, ambas as formas são relatadas no português: entrar intrar. A confusão atingiu outros itens lexicais iniciados com a vogal /e/, produzindo formas como exemplo > enxemplo > inxemplo > ixemplo; exame > enxame > inxame > ixame. Naro conclui, então, que "o português do século XVI tinha $e$ - como [i] em en- e es- (através de ens-) e talvez em esC-, mas não em outras iniciais" (NARO, 1973, p. 40).

No século XVIII, o quadro vocálico do português europeu (PE) foi alterado com o processo de redução sofrido pelas pretônicas médias. A posterior /o/ passou a ser produzida como [u], e a anterior /e/, como [ə]. Formas como cutovelo para cotovelo, murar para morar, xuver para chover são encontradas no Compendio de Ortographia de Luís do Monte Carmelo, de 1767 (apud TEYSSIER, 2004, p. 75). Os ambientes, porém, que continham a forma média-aberta permaneceram inalterados, como pode ser verificado nas listas fornecidas por Monte Carmelo: cògniçâm; adòptar; dèlgada; fèlpudo (cf. SILVA, 1989, p. 54-55). Segundo Teyssier (2004, p. 77), o quadro fonológico das vogais pretônicas no início do século XIX pode ser assim representado:

Revista Letras, correspondem, respectivamente, a /ẹ/, /ọ/, /ę/, /ǫ/ e /ä/ usados por Teyssier.

Curitiba, UFPR, n. 96, pp.104-131,

jul./dez. 2017. ISSN 2236-0999 (versão eletrônica) 


\begin{tabular}{|l|l|l|}
\hline $\mathrm{i}$ & & $\mathrm{u}$ \\
\hline & $\partial$ & $\mathrm{o}$ \\
\hline$\varepsilon$ & $\mathrm{e}$ & $\mathrm{J}$ \\
\hline & $\mathrm{a}$ & \\
\hline
\end{tabular}

Quadro 2: Quadro fonológico das vogais pretônicas do português europeu no século XIX

Fonte: Teyssier (2004, p. 77) ${ }^{2}$

Ainda com oito fonemas, o quadro das vogais pretônicas diferencia-se do das tônicas, conforme exposto no Quadro 3:

\begin{tabular}{|l|l|l|}
\hline $\mathrm{i}$ & & $\mathrm{u}$ \\
\hline $\mathrm{e}$ & & $\mathrm{o}$ \\
\hline & $\mathrm{e}$ & $\mathrm{J}$ \\
\hline & $\mathrm{a}$ & \\
\hline
\end{tabular}

Quadro 3: Quadro fonológico das vogais tônicas do português europeu do século XIX Fonte: Teyssier (2004, p. 77)

É esse sistema vocálico que Gonçalves Viana descreve no final do século XIX, em Essai de phonétique et de phonologie de la langue portugaise d'après le dialecte actuel de Lisbonne, publicado em 1883. Uma das percepções mais evidentes é a de que a flutuação no ambiente pretônico persistiu. Em discussões linguísticas com Leite de Vasconcelos via carta, Viana escreve: "e inicial, se o accento não está na seguinte syllaba, soa em geral è na pronúncia culta de cá, por ex., Hèrculano; ainda assim ha fluctuação (...) Sei também que para o norte $o$ isolado inicial soa $u$; aqui soa $\grave{o}$, ou entre gente culta $\hat{o}$, ex. olhar" (VASCONCELOS, 1973, p. 25-26). Em outra carta, outra regra é relatada: "O $l$ influe na vogal, tornando-a aberta, o $r$ não, em português. As formas Nàrciso, Guilhèrmino etc. devem ser atribuídas a accento secundário" (VASCONCELOS, 1973, p. 30).

Os ambientes favorecedores para a elevação e para o abaixamento citados por Gonçalves Viana no seu trabalho com o PE indicam uma continuidade da coocorrência de muitas das formas encontradas nos séculos anteriores. As contrações provenientes do latim determinam uma pronúncia mais aberta das vogais, "indiquent dans la plupart des cas la disparition d'une consonne, d'une voyelle, ou d'une syllabe entière”. (GONÇALVES VIANA, 1973, p. 98). Essa regra vale para as médias /e/ e /o/, assim como para a baixa /a/. Exemplos fornecidos pelo autor são:

$$
\begin{aligned}
& \text { pàdeiro < paadeiro } \\
& \text { càveira < caaveira }
\end{aligned}
$$

2 O símbolo /ə/, corresponde a /ë/, encontrado no texto de Teyssier (2004). 


\section{G. S. Graebin}

A Pronúncia das

Vogais Médias

no Português

Europeu e

no Português

Brasileiro: $u m$ estudo diacrônico crèdor < creedor < creditorem

aquècer < aqueecer < calescere

A pronúncia média-aberta também ocorre em palavras com sílabas travadas $^{3}$

Le verbe assez moderne optàr se prononce òptár, le verbe plus ancien adoptar se prononce adòtár et non pas adòptár ou ạdutár. Le $p$, de même que le $c$, est généralement nul devant $t$; il rend ouvertes, cependant, les $a, e, o$, qui le précèdent, et qui sans cette consonne seraient devenues $a, e, u$, en perdant l'accent. ${ }^{4}$ (GONÇALVES VIANA, 1973, p. 99)

Outro ambiente favorecedor para a abertura da vogal /o/ - e também da /a/ - é a sílaba travada no início de palavra, como em òrtelãu, òspedar, àrmáriu. Gonçalves Viana (1973, p. 112) sublinha, entretanto, que esta pronúncia é mais geral entre o povo, não entre a gente culta. Já a elevação, observa Gonçalves Viana (1973, p. 112), é atestada para a vogal /e/ quando está no início da palavra, em sílaba aberta ou em sílaba fechada por fricativa alveolar e nasal. Elogio, esposo e entrei se pronunciam, respectivamente, ilujiu, ispôso, intrei.

A pesquisa dialetológica de Leite de Vasconcelos (1901), realizada em período análogo ao de Gonçalves Viana, revela as diferenças dialetais entre as regiões Norte, Centro e Sul de Portugal. A vogal anterior /e/ "non suivi de $s$ impur est representé par $i$ (comme dans la langue littéraire) dans le Nord, dans le Centre et dans l'Estremadure Cistagane, et par ê- dans l'Estremadure Transtagane, dans l'Alemtejo e dans l'Algarve"5 (p. 99-100). Em contexto nasal, Vasconcelos (1901) verifica que "l'- ẽ initial a une destinée analogue à celle de $e-$ d'une manière générale, on peut dire que $\widetilde{e}$ devient $\tilde{\imath}$ - dans le Nord, dans le Centre et dans l'Estrémadure Cistagane, $\widetilde{e}-$ plus au Sud; ex.: intrar, entrar"\% (p. 100). Em posição medial de palavra, a variação da pretônica /e/ em uma palavra como lembrar pode ser (p. 100-101):

Revista Letras,

Curitiba, UFPR,

n. 96, pp.104-131,

jul./dez. 2017.

ISSN 2236-0999

(versão eletrônica)

3 Os símbolos a, e, u, usados por Gonçalves Viana correspondem, respectivamente, a [e], [ə] e [v] do Alfabeto Fonético Internacional.

4 Tradução nossa: "O verbo mais moderno optàr se pronuncia òptár; o verbo mais antigo adoptar se pronuncia adòtár e não ạdòtár ou ạdutár. O $p$, assim como o $c$, é geralmente mudo diante de $t$; permanecem abertos, entretanto, os $a, e, o$, que os precedem, e que sem essa consoante seriam $a, e, u$, perdendo o acento".

5 Tradução nossa: "não seguido se $s$ é representado por $i$ (como na língua literária) no Norte, no Centro e na Estremadura ao norte do Tejo, e por $\hat{e}$ - na Estremadura ao sul do Tejo, no Alentejo e no Algarve".

6 Tradução nossa: "o $\widetilde{e}$ - inicial tem uma pronúncia análoga à de $e$-: de uma maneira geral, pode-se dizer que $\tilde{e}$ é pronunciado $\tau$ - no Norte, no Centro e na Estremadura ao norte do Tejo, $\widetilde{e}$ - mais ao Sul de Portugal: ex.: intrar, entrar". 
- lembrar - no Algarve, em grande parte do Alentejo e em uma parte de Beira-Alta;

- leimbrar - no "concelho" de Baião, no Mesão-Frio, em Alvações e na Villa-Real;

- lembrar - no Minho e em grande parte de Trás-os-Montes e da BeiraAlta;

- limbrar - em algumas regiões ao Norte de Tras-os-Montes, em uma parte da Beira e do Alto-Alentejo, e na Estremadura;

- lambrar - no Alto D’Ouro.

Para a vogal média posterior /o/, Vasconcelos (1901, p. 101) afirma que a variação, em posição inicial, é paralela a da vogal anterior /e/: "L'o initial est généralement representé par ô- ou ó- dans l'Estrémadure, dans la plus grand partie de l'Alemtejo et dans l'Algarve; par öu- dans quelques point du Nord de Tras-os-Montes, par $u$ - dans le reste du pays. ${ }^{8}$ Exs.: ôrelha, órelha, urelha (ureilha), öubedecer" . Em contexto inicial nasal, a média posterior pode elevar ou não. É produzida como õ- no Algarve e no Alentejo, e como ũ- ou ó- no resto do país. Vasconcelos fornece o seguinte exemplo: onzeneiro, unzeneiro. O contexto nasal situado em posição medial de palavra também propicia variação. A palavra comprar pode ser produzida de três maneiras (VASCONCELOS, 1901, p. 102):

- comprar - no Algarve, no Baixo-Alentejo, em uma parte do AltoAlentejo e em uma parte da Beira Alta;

- cómprar - no concelho de Baião, em Mesão-Frio e em outras regiões do Norte;

- cumprar - no Alto e Baixo-Minho, em uma grande parte de Trás-osMontes e da Beira-Alta, e em toda a Estremadura.

Ocorrências de assimilação, dissimilação, redução e variação dialetal são registradas também na obra de José Joaquim Nunes, Compendio de Gramática Histórica, publicado pela primeira vez em 1919. Para o autor, a presença de variação no ambiente pretônico é proveniente do latim vulgar. A assimilação (NUNES, 1960, p. 60) - ou harmonização vocálica - é constatada em palavras como mentire - mintir; ${ }^{\star}$ petire - pidir; vestire - vistir; ferire - firir; ${ }^{\star}$ consuetumine - custume. A dissimilação, segundo Nunes, é um hábito antigo da língua portuguesa:

7 O símbolo e usado por Leite de Vasconcelos corresponde a [ə] no Alfabeto Fonético Internacional.

8 Não fica claro no texto de Vasconcelos a qual pronúncia o símbolo öu se refere. Por esse motivo, não estabelecemos uma correlação com o Alfabeto Fonético Internacional.

9 Tradução nossa: "O o inicial é geralmente representado por $\hat{o}$ - ou $o ́$ - na Estremadura, na maior parte do Alentejo e no Algarve; por öu- em alguns pontos no Norte de Trás-os-Montes, por $u$ - no resto do país. Exs.: ôrelha, órelha, urelha (ureilha), öubedecer"” 


\section{G. S. Graebin}

A Pronúncia das

Vogais Médias

no Português

Europeu e

no Português

Brasileiro: $u m$

estudo diacrônico esta troca está tanto nos nossos lábios que pessoas cultas mesmo, quando falam descuidadamente, a praticam. (...) Em qualquer período da língua encontram-se grafias como estas: dessimular, deferença, defamar, vertude, vertuoso, deficuldade, descreto, defusão, vezinho, trebuto, etc., e, em sílaba não inicial, restetuir, ponteficado, marterizar, lágrema, openião, ordenário, etc. (NUNES, 1960, p. 62)

Nunes (1960, p. 56) explica que, em posição medial da palavra, as pretônicas /e/ e /o/ são mais suscetíveis à redução do que aquelas que estão em posição inicial ou final de palavra: "A sorte das vogais átonas depende do lugar que ocupam na palavra e de sua posição relativamente ao acento tónico, sendo as iniciais e as finais as que mais resistências possuem; as médias atenuam-se por tal forma que desaparecem frequentemente".

A respeito da variação dialetal, Nunes relata que

em algumas falas populares do país, com excepção das duas províncias ao sul do Tejo, e já desde o século XVI pelo menos, soa $\tilde{\imath}^{-}$a vogal nasal $\tilde{e}-$, quer resultante de $\tilde{a}-$, quer originária, sem dúvida pela mesma razão porque a oral $e$ vale de $i$ nas mesmas falas. (...) Pelo mesmo motivo, ou antes por influência literária, diz-se e escreve-se hoje inteiro, inveja, injúria, infinda, ingratidão, em vez de enteiro, enveja, enjúria, engratidão, como regularmente diziam e escreviam os nossos antigos (NUNES, 1960, p. 64).

O estudo de Morais Barbosa (1965), Etudes de phonologie portugaise, já em meados do século XX, procura definir quais são de fato os fonemas vocálicos do PE. O autor observa que as alternâncias entre as formas médias-fechadas, médias-abertas e altas, já consideradas acima, ainda são frequentes. Para uma melhor compreensão dos contextos dessas variações, Barbosa estabelece dois quadros do sistema vocálico em posição pretônica: um para a posição inicial de palavra e outro para a posição medial.

Quando uma palavra é iniciada por uma vogal pretônica, travada ou não por consoante, Barbosa atesta nove possibilidades: [i e $\varepsilon$ a $\mathrm{e}$ ə $\supset$ o u]. $\mathrm{Na}$ série posterior, /o/ é realizado como [o] diante de /R/, e até como [u] em outros ambientes, por pessoas com pouca escolaridade. É o caso de palavras como operário, hospedar, ouvir. Segundo o autor, a forma média-fechada [o] é a utilizada pela classe instruída (cf. BARBOSA, 1965, p. 136). A observação de Barbosa, nesse aspecto, coincide com a de Gonçalves Viana a respeito do abaixamento da vogal /o/. O autor conclui, então, que [u] e [j] são alofones do fonema /o/.

Revista Letras,

Curitiba, UFPR, n. 96, pp.104-131, jul./dez. 2017. ISSN 2236-0999 (versão eletrônica) 
A variação para a série anterior é mais complexa, sendo que o fonema le/ pode ser produzido como [e], [E], [ $\mathrm{e}]$ e [i]. Nem todos os ambientes são produtivos para as quatro possibilidades:

- Em sílabas abertas, apenas a variação entre [e] e [i] é encontrada, como em elegante $\sim$ ilegante.

- Em sílabas travadas, ou seja, com coda, a variação entre [e] ou [є] é foneticamente condicionada. A variante média-aberta é encontrada diante de /L/ e /R/, - Èldorado; èrvanário - enquanto a média-fechada diante de /N/ e /W/ - entrar; Europa. Assim, [e] e [E] são duas variantes do fonema /e/.

- Diante de /N/, é possível encontrar três variantes: a média-fechada [e], a alta [i], e o ditongo nasal [ei]. Barbosa (1965, p. 137) relata que a

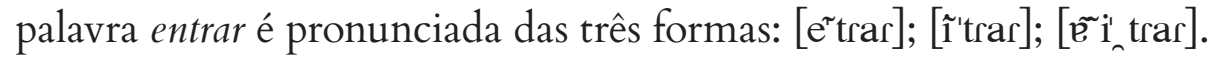

- Diante de /S/, o fonema /e/ varia entre as formas [e] e [ə] e [ei]. A palavra estar pode ser pronunciada tanto [e $\left.\int^{\prime} \operatorname{tar}\right]$ como [ə]'tar]. Já a palavra exterior apresenta três possibilidades: [efteri'or], [əfteri'or] e [eifteri'or].

Para Barbosa (1965), portanto, o quadro das vogais, em posição inicial, pode ser resumido a 6 fonemas, conforme o Quadro 4:

\begin{tabular}{|l|l|l|}
\hline $\mathrm{i}$ & & $\mathrm{u}$ \\
\hline $\mathrm{e}$ & & $\mathrm{o}$ \\
\hline & $\mathrm{e}$ & \\
\hline & $\mathrm{a}$ & \\
\hline
\end{tabular}

Quadro 4: Quadro fonológico das vogais pretônicas em posição inicial de palavra no português europeu do século XX

Fonte: Barbosa (1965, p. 142)

Quando a pretônica encontra-se em uma sílaba no meio da palavra, ocorrem as mesmas 9 possibilidades de fones daquelas encontradas em posição inicial: [i e $\varepsilon$ a $\boldsymbol{\varepsilon}$ ə э o u ]. Os fonemas decorrentes de oposições, entretanto, sobem de 6 para 8, como mostra o Quadro 5: 
G. S. Graebin

A Pronúncia das

Vogais Médias

no Português

Europeu e

no Português

Brasileiro: um estudo diacrônico

\begin{tabular}{|l|l|l|}
\hline $\mathrm{i}$ & & $\mathrm{u}$ \\
\hline $\mathrm{e}$ & & $\mathrm{o}$ \\
\hline & $\mathrm{e}$ & $\mathrm{J}$ \\
\hline & $\mathrm{a}$ & \\
\hline
\end{tabular}

\section{Quadro 5: Quadro fonológico das vogais pretônicas em posição medial de palavra no português europeu do século $X X$}

Fonte: Barbosa (1965, p. 152)

A diferença entre as duas posições está no acréscimo das vogais médiasabertas [ع]. O fonema / / se distingue de /o/ nessa posição, porque forma pares mínimos, como o seguinte: pòsar - pousar (BARBOSA, 1965, p. 144). A pronúncia média-aberta [0] é usada apenas em sílabas abertas, guardando a marca da consoante ou do hiato latinos perdidos em palavras como còrar; adòpção. Barbosa (1965) não relata casos de elevação da média posterior /o/ nessa posição.

Para a série anterior, Barbosa (1965, p.152-53) registra, em posição medial de palavra, várias neutralizações, ou seja, perda de oposição entre os fonemas /e/ e / / /, em alguns ambientes específicos: (i) em sílabas com coda em /L/, contexto em que apenas a forma $[\varepsilon]$ ocorre - dèlgado, rèlvar; (ii) em sílabas com coda em /N/, /W/, /R/ e /S/, ambiente em que apenas o fonema /e/ aparece. Com /N/ e com /W/, representada pela variante [e] - pensar, neurose -, e com /R/ e /S/, pela variante [ə] - perdido, pescar. Em sílabas abertas, a oposição entre as vogais média-fechada [e] e média-aberta [ $\varepsilon$ ] é mantida, como, por exemplo, entre pregar (sermão) e prègar (com martelo).

Assim, a partir do estudo de Barbosa (1965), é possível distinguir o quadro vocálico fonético do quadro fonológico do PE, demonstrado no Quadro 6:

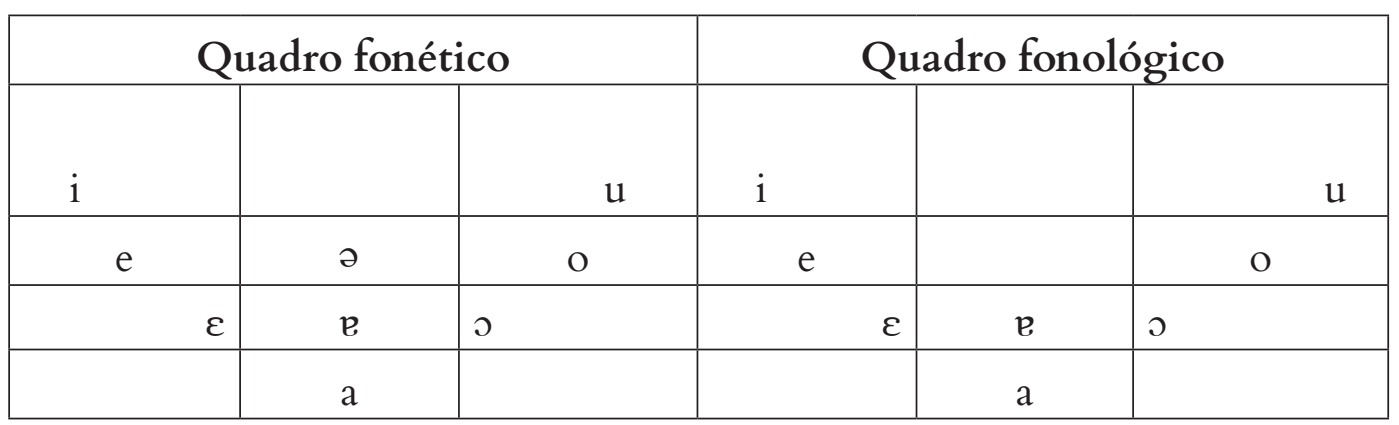

Quadro 6: Comparação entre os quadros fonético e fonológico das vogais médias pretônicas do português europeu do século $\mathrm{XX}$

Fonte: Barbosa (1965, p. 152-153)

Após essa exposição, que tentou perseguir o caminho trilhado pelas pretônicas médias no PE, podemos observar que a variação, desde o século XVI, é um processo inerente ao sistema vocálico. As variantes abaixadas [ $\varepsilon]$ e [o], como marca da queda dos hiatos latinos, assim como o processo de redução, indicam
Revista Letras,

Curitiba, UfPr, n. 96, pp.104-131, jul./dez. 2017. ISSN 2236-0999 (versão eletrônica) 
mudanças já concretizadas na língua. As outras variações encontradas parecem estar em uma situação estável de coocorrência. Não apenas fatores linguísticos são desencadeadores da variação; os fatores sociais e geográficos também exercem determinada força: o nível de escolaridade interfere na produção das pretônicas em Lisboa, segundo o estudo de Gonçalves Viana (1973 [1883]) e Barbosa (1965), e a área geográfica acarreta diferenciações na pronúncia, como indicam as pesquisas de Vasconcelos (1901) e Nunes (1960).

\section{Português brasileiro}

Implantação do Português no Brasil

No Brasil, o português demorou a ser a língua predominantemente falada pela população. Apenas no século XVIII, a partir da política pombalina - que incluía a expulsão dos jesuítas e a proibição do uso da língua geral -, o português tornou-se a língua oficial (cf. HONÓRIO RODRIGUES, 1983, p. 33-4). Até então, o que prevalecia eram as chamadas línguas gerais, uma delas falada na região de São Paulo - amplamente utilizada pelos bandeirantes -, e a outra falada na região amazônica (cf. RODRIGUES, 1996). Na definição de 114 Rodrigues (1996),

\footnotetext{
A expressão língua geral tomou um sentido bem definido no Brasil nos séculos XVII e XVIII, quando, tanto em São Paulo como no Maranhão e Pará, passou a designar as línguas de origem indígena faladas, nas respectivas províncias, por toda a população originada no cruzamento de europeus e índios tupi-guaranis, (...) à qual foi-se agregando o contingente de origem africana e contingentes de vários outros povos indígenas. (RODRIGUES, 1996, p. 6)
}

Dadas as dificuldades encontradas pela língua portuguesa de disseminarse pelo território brasileiro, não apenas por conta das línguas gerais, mas por diversos outros fatores, como a carência de uma política educacional, a extensão do território e a grande quantidade de línguas e etnias, a história da língua portuguesa no Brasil ainda hoje é assunto de especulação. Mattos e Silva (1992, p. 76) admite: "Passados quase cinco séculos, está ainda por ser reconstruído o processo do encontro, politicamente assimétrico, entre a língua portuguesa, 
G. S. Graebin A Pronúncia das

Vogais Médias no Português

Europen e

no Português

Brasileiro: um estudo diacrônico

língua de dominação, as muitas línguas autóctones e as diversas línguas aqui chegadas". O projeto coordenado por Ataliba Castilho, Projeto nacional para a história do português brasileiro, vem, desde 1996, tentando sanar essa lacuna.

$\mathrm{O}$ que se tem afirmado quanto à implantação do $\mathrm{PE}$ no Brasil é que não houve, dentre todas as variedades faladas em Portugal, uma que fosse predominante. Segundo o relatório divulgado após a primeira visita do Santo Ofício às regiões do Brasil, no final do século XVI, analisado por Silva Neto (cf. 1979, p. 583-584), houve equilíbrio quanto à origem dos portugueses para cá emigrados: "por muito precários que possam ser os elementos de que dispomos, estes conduzem sempre à conclusão de que os colonos vieram de todos os pontos de Portugal” (SILVA NETO, 1979, p. 585). Além disso, Silva Neto sustenta o seguinte argumento:

Acreditamos, pois, que, na Colônia, portugueses de todas as partes se fundiram em contacto e interação, eliminando, expurgando os difíceis fonemas do Norte, os tipicismos que podiam levar à sanção do ridículo, as particularidades que diante da língua comum se poderiam considerar "rusticismos" (...) Realmente, a pronúncia brasileira, ainda que, no seu conjunto, seja bastante conservadora, não guarda nenhum dos traços típicos da pronúncia do Norte de Portugal. (SILVA NETO ,1979, p. 589)

A mesma posição é defendida por Teyssier (cf. 2004, p. 98), o qual afirma que o português falado no Brasil representa a reunião dos dialetos falados pelos colonos provenientes de todas as regiões de Portugal: uma koiné. Essa língua comum teria dado preferência às formas de prestígio faladas no Centro-Sul de Portugal - onde está situada Lisboa -, generalizando-as e, ao mesmo tempo, procurando eliminar os traços marcados dos dialetos do Norte, como a pronúncia africada $[\mathrm{t}]$ - tch - nas palavras chapéu e chave.

Pode-se questionar, contudo, até que ponto as variedades do PE se fundiram numa koiné, já que o português brasileiro (PB) não é, de forma alguma, uma língua homogênea. Assim, se por um lado, a língua portuguesa foi a língua que venceu no território brasileiro - usando os mesmos termos de Honório Rodrigues (1983) -, por outro, esta mesma língua está dividida em diferentes variedades, conforme a região em que é falada: "A vitória real e verdadeira veio quando os representantes de várias províncias brasileiras falaram uns com os outros na Assembléia Constituinte de 1823, notando as diferenças de prosódia, mas a igualdade da língua que todos falavam” (HONÓRIO RODRIGUES, 1983, p. 40).

Revista Letras,

Curitiba, UFPR, n. 96, pp.104-131, jul./dez. 2017. ISSN 2236-0999 (versão eletrônica) 
Igualmente questionável é a eliminação dos traços marcados atribuídos às variedades faladas no Norte de Portugal. Segundo Almeida (2005, p. 87), a pronúncia / $\mathrm{t} f /$ - tch - em palavras como chegar, chá e peixe na Baixada Cuiabana pode ser não apenas uma particularidade da fala local, mas um indício da manutenção de uma antiga pronúncia utilizada no período Colonial: "A realização da africada /t $\mathrm{f} /$ do ch gráfico, em regiões mal delimitadas de São Paulo, Paraná e Mato Grosso, neste último, agora já bem delimitada - a Baixada Cuiabana -, é vista por Celso Cunha como uma pronúncia que já era a mais geral no século XVI".

E embora sejam escassos os documentos referentes à proveniência dos colonos portugueses, conforme a citação de Silva Neto acima, ele próprio (cf. 1979, p. 584-85) menciona a possibilidade de tanto a Bahia quanto Pernambuco terem recebido uma quantidade maior de emigrantes da região Norte de Portugal. Os documentos referentes à segunda visita do Santo Ofício à Bahia em 1618 (SEGUNDA visitação do Santo Ofício às partes do Brasil, 1963), não incluídos na pesquisa de Silva Neto, listam, dentre as 73 pessoas ouvidas, 48 portugueses, dos quais 19 se identificaram como procedentes da região Norte, 16 da região Sul, 3 da região Central, e 5 procedentes das ilhas. ${ }^{10} \mathrm{Um}$ número um pouco maior, portanto, de nortistas. Assim, não se pode descartar, de todo, uma interferência maior de uma ou outra variedade portuguesa em determinadas regiões do Brasil, sendo possível levantar a hipótese de que os dialetos portugueses falados ao Norte de Portugal tenham desempenhado um papel diferenciado em locais como a Bahia e Pernambuco. Seguindo essa linha de raciocínio, poderíamos dizer que uma das razões motivadoras para a variação diatópica no $\mathrm{PB}$ é a presença desse tipo de variação no $\mathrm{PE}$, conforme vimos acima no trabalho de Vasconcelos (1901, p. 99-102). Tal hipótese questiona a formação de uma koiné, pelo menos nos moldes defendidos por Silva Neto e Teyssier.

Semelhanças e contrastes com o PE

Desde as primeiras comparações a que temos acesso entre o $\mathrm{PB}$ e o $\mathrm{PE}$, atestam-se tanto diferenças quanto similaridades entre a língua da colônia e a da metrópole. Teyssier (2004) observa que

Em 1767, Frei Luís do Monte Carmelo (Compendio de ortographia) assinala pela primeira vez um traço fonético dos brasileiros, que é o de não fazerem distinção entre as pretônicas abertas (ex.: pàdeiro, prègar, còrar) e as fechadas (ex.:

10 Os documentos referentes à Segunda Visita do Santo Ofício à Bahia foram cordialmente concedidos pela Profa. Dra.Suzana Alice Marcelino Cardoso (UFBA). 


\section{G. S. Graebin}

A Pronúncia das

Vogais Médias

no Português

Europeu e

no Português

Brasileiro: um estudo diacrônico cadeira, pregar, morar). Jerônimo Soares Barbosa (Grammatica Philosophica, 1822) salienta o mesmo fato e acrescenta que os brasileiros dizem minino (por menino), mi deu (por me deu); que não chiam os $-s$ implosivos (mistério, fasto, livros novos). (TEYSSIER, 2004, p. 95)

Como veremos a seguir, nem todas as diferenças observadas por Monte Carmelo e Soares Barbosa podem ser confirmadas. Em alguns aspectos, o PB se aproxima do PE, perpetuando determinados traços.

A continuidade de traços é percebida, por exemplo, na afirmação de Soares Barbosa na citação acima. $\mathrm{O}$ fato de os brasileiros pronunciarem minino demonstra que a variação, inerente ao $\mathrm{PE}$, é simplesmente repassada para o $\mathrm{PB}$, ou seja, esse traço característico é conservado. A elevação regida pela assimilação perpassou todas as variedades faladas no Brasil, sendo hoje um fenômeno supradialetal. É registrada na fala de várias regiões:

- na fala carioca por Nascentes (1953, p. 29, 35): minino, pidí, cuzinha, curtina;

- na fala paulista por Amaral (1920, p. 23, 24): pirigo, dilicado, minino, atrivido, intiligente, pidí, midí, ingulir, bulir, tussir, surtir;

- na fala goiana por José Teixeira (apud ELIA, 1963, p. 254): siguro, minino, mintiroso, sirviço, disunião, discretada, ufindido, niguciante, dilicado, arripindido, pelijá, divoto, divução, puvuação, nutiça, cumitiva, suciedade;

- na fala nordestina por Marroquim (1934, p. 47, 56, 57, 72): pidir, izistir, encubrir, cubrir, durmir, surrir, bulir, ingulir, currida, pulimento, dumingo, cumida, lumbriga, muldura, binifiço, puliça, nutiça;

- na fala gaúcha por Elpídio Paes (apud ELIA, 1963, p. 256): bunito, muldura, culuna, cubrir, curtir, durmir, ingulir, bulir, descubrir, assim como os nomes correspondentes a esses itens cuberta, curtume, durminhoco.

A harmonização vocálica - ou assimilação do traço [+ alto] - ocorre não apenas entre as vogais homorgânicas, ou seja, aquelas realizadas na mesma zona de articulação, mas também entre as não-homorgânicas. Serafim da Silva Neto (1963, p. 172-175) fornece uma relação de palavras harmonizadas como resultado de quatro combinações:

- homorgânicas anteriores - $e-i>i-i$ : filiz, pipino, midida, minino, firida, pirigo, avinida, bem-ti-vi;

- homorgânicas posteriores - o-u> u-u: gurdura, furtuna, custume, curtume, currupção.
Revista Letras,

Curitiba, UFPR,

n. 96, pp.104-131,

jul./dez. 2017.

ISSN 2236-0999

(versão eletrônica) 
- não-homorgânicas - $e-u>i-u$ : viludo, siguro, piludo; $-i>u$-i: urtiga, cubiça, muringa, fucinho, butina, curtina, bunito.

Silva Neto (1963, p. 173) reconhece, todavia, que a assimilação é uma regra variável, pois nem sempre palavras que contêm um ambiente fonético favorável, i.e., pretônicas médias /e/ e /o/ seguidas de vogais altas /i/ e /u/, harmonizamse. É o caso de verdura, mortificar, domínio. O oposto também é verdadeiro: palavras que não apresentam um ambiente favorável para a harmonização são pronunciadas da forma elevada: fugueira, buneca, sutaque. Nascentes (1965) faz a mesma observação:
A influência de $i$ e $u$ tônicos, posteriores, as tornam reduzidas. Assim, escrevi (pronuncie-se iscrivi e não êxcrêvi), devia (divia), mesquinho (misquinho), absoluto (absulutu), coruja (curuja). (...) Em outros casos, não se pode atribuir esta redução nem a $i$ nem a $u$ tônicos: presunto (prizunto), sociedade (suciedade), colégio (culégio), comédia (cumédia). (NASCENTES, 1965, p. 14-15)

A vogal /e/ em posição inicial de sílaba pode tanto sofrer elevação quanto permanecer média-fechada. Nascentes (1965) propõe algumas regras, mas as exceções são inevitáveis:

\begin{abstract}
A vogal $e$ é reduzida também nas sílabas iniciais átonas em, en, es, ex: embeber, encanto, estar, exclamar (...). Em palavras como eminente, energia, esôfago, exótico, em que o $m$, o $n$, o $s$, e o $x$ não fazem parte da sílaba inicial, a vogal $e$ inicial é fechada. Excetua-se emenda, que se pronuncia imenda. Entretanto, principalmente em palavras não eruditas, aparece o $e$ reduzido: exagero, exame, erigir, exalar, exaltar, exausto, exigir, existir, hesitar. Nos compostos de entre, apesar de o $n$ fazer parte da sílaba inicial, o $e$ antes dele é fechado, ex.: entremeio. Explica-se isso pela influência da palavra simples, entre. (NASCENTES, 1965, p. 13)
\end{abstract}

A elevação de /e/ em início de sílaba pode, por vezes, vir acompanhada de nasalização, o que não é nenhuma inovação na língua portuguesa. No Rio de Janeiro, Nascentes (1953, p. 32) registra inrado, inducá, inlugio, inleição para errado, educar, elogio, eleição. A extensão da nasalidade é igualmente verificada na vogal /o/ da fala nordestina (MARROQUIM, 1934, p. 59): cunsinha, cunsinhá, gunverno, gunverná, gunvernadô.

Outro ambiente favorável à elevação no PB herdado do PE é o hiato: 
G. S. Graebin

A Pronúncia das

Vogais Médias

no Português

Europeu e

no Português

Brasileiro: um

estudo diacrônico
- em rial, lial, lião e tiatro para real, leal, leão, teatro (NASCENTES, 1953, p. 29);

- em muê, duê, puêra para moer, doer, poeira (PAES apud ELIA, 1963, p. 256);

- em passiar, vuar, pueta para passear, voar, poeta (NASCENTES, 1965, p. 16, 17).

A verdade é que a variação é tão recorrente que Silva Neto (1963, p. 175) afirma: "podem mesmo notar-se na pronúncia da mesma pessoa, uma pronúncia tensa outra distensa: dormir/durmir". O mesmo fato impele Nascentes (1965) a elaborar listas para orientar o falante quando deve usar a variante média-fechada [e o] ou a alta [i u], que ele chama de timbre reduzido:

Há indecisões do timbre do $e$ em muitas palavras. Aconselhamos (...) o e reduzido em paletó. (...) $\mathrm{O} e$ da preposição de é pronunciado fechado em algumas expressões, como de tarde, de noite, cor de rosa, pão-de-ló, conto de réis, de repente, depressa. (...) Aconselhamos o timbre reduzido do o em política, colégio e nas preposições por, porque, porquanto, portanto, porventura. (NASCENTES, 1965, p. 13-15)

Cabe ainda citar um aspecto da variação observado por Silva Neto (1963): o uso da variante elevada pode servir como indicador de distinção semântica.

Quando formamos diminutivo de palavras que tem $o$ tônico, mantemos o timbre da vogal: corpo-corpinho, folha-folhinha; quando, porém, a palavra tem a mesma estrutura mas se perdeu a noção de que se trata morfologicamente de um diminutivo, a vogal pretônica tende a atenuar-se: folhinha (= fulhinha, calendário), corpinho (= curpinho, colete de senhora) (SILVA NETO, 1963, p. 172)

Se, por um lado, o PB se aproxima do PE por conservar a variação das pretônicas nos ambientes acima citados, por outro se distancia, uma vez que a pronúncia do $\mathrm{PB}$, como escreve Teyssier (2004, p. 101), perpetua "a pronúncia de Portugal antes das grandes mutações fonéticas do século XVIII”. O PB

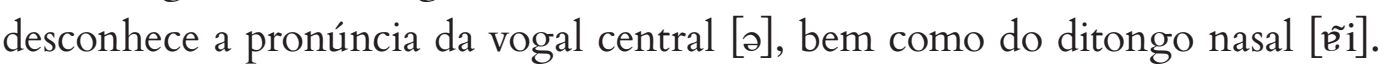
Verdade é que os resultados, especialmente pelo fato de Brasil e Portugal estarem geograficamente distantes, apontam dois rumos distintos na língua portuguesa:
Revista Letras,

Curitiba, UfPr, n. 96, pp.104-131, jul./dez. 2017. ISSN 2236-0999 (versão eletrônica) 
enquanto no $\mathrm{PB}$ as vogais pretônicas são, geralmente, bem pronunciadas, e algumas vezes até alongadas, no PE, a duração dessas vogais é bastante reduzida, de tal modo que, como escreve Barbosa (cf. 1965, p. 11), um estrangeiro tem a impressão de que os portugueses "comem" as vogais:

Le portugais se présente à un étranger comme une langue où le nombre de consonnes l'emporte de très loin sur celui des voyelles et où la plupart des phrases paraissent reduites à leur squelette consonantique, entrecoupé çà et lá par une voyelle accentuée ou, plus rarement, par une voyelle inaccentuée échappant a une telle 'réduction' (BARBOSA, 1965, p. 13). ${ }^{11}$

A esse respeito observa Elia (1963, p. 280), "no Brasil o vocalismo é tenso, ao passo que o consonantismo é distenso e que o inverso se verifica em Portugal".

Castilho (2006, p. 244) observa que o PB tem sido interpretado por "duas posições antitéticas (...), ora como uma modalidade conservadora, que reflete o falar quinhentista trazido pelos colonizadores, ora como modalidade inovadora, que se afasta a passos rápidos do PP [Português de Portugal]”. A nosso ver, as duas posições se complementam, pois, se por um lado o PB é conservador, por preservar traços do PE quinhentista, por outro, a língua falada no Brasil não ficou estagnada, mas passou por mudanças e, portanto, cabe ao PB também o atributo de inovador. A expressão "arcaicidade dinâmica" é utilizada por Elia (1963, p. 282) para dar conta do paradoxo entre conservação e inovação no PB. Nesse sentido, Silva Neto (1963, p. 208) reconhece: "Ao português brasileiro podemos, portanto, atribuir características opostas: particularidades arcaicas e novos desenvolvimentos".

Um dos novos desenvolvimentos operados pela língua portuguesa falada no Brasil encontra-se justamente no ambiente pretônico e é tema de debate ainda não solucionado. Retomamos aqui a citação dos portugueses Monte Carmelo e Soares Barbosa (apud TEYSSIER, 2004, p. 95), quando afirmam que uma das primeiras diferenças percebidas entre o PB e o PE repousa no fato de os brasileiros não distinguirem pretônicas abertas de fechadas, como em prègar e pregar. Isso é verdadeiro em parte. Por alguma razão desconhecida, o PB tomou um rumo nas regiões Sul e Sudeste do país e outro nas regiões Norte e Nordeste. É o que verifica Nascentes (1965, p. 39): “em matéria de linguagem o nosso país pode dividir-se em duas grandes regiões: Norte, do Amazonas e do Pará até a Bahia, e Sul, do Espírito Santo até o Rio Grande do Sul”. Segundo Nascentes, essa divisão é motivada pela pronúncia das vogais e pela entoação. Também Silva Neto (1963, p.189) registra: "na pronúncia do Nordeste, numa área por definir, 11 Tradução nossa: "Para um estrangeiro, o português se apresenta como uma língua em que o número de consoantes supera, de longe, o de vogais, e em que a maioria das frases parecem reduzidas a seu esqueleto consonântico, alternadas aqui e lá por uma vogal acentuada ou, mais raramente, por uma vogal átona que escapou à 'redução". 
G. S. Graebin A Pronúncia das

Vogais Médias no Português

Europen e

no Português

Brasileiro: um estudo diacrônico mas com toda a segurança muito extensa, todas as vogais pretônicas são abertas; assim: dèzembro, tòlerar".

Dois aspectos podem ser levantados para tentar solucionar essa questão. Um linguístico e outro histórico. A pronúncia aberta e a entoação "cantada" nordestinas são atribuídas por vezes à influência indígena. $\mathrm{O}$ argumento usado por Elia (1963, p. 300) é: "A modulação nordestina é diferente da do resto do país, sendo talvez de origem índia. A protônica aberta seria, portanto, um ponto de apoio necessário à fala cantada do nordestino". Silva Neto (1963) não descarta de todo essa hipótese, embora julgue que deva ser melhor apurada; propõe outra possibilidade - ao mesmo tempo que a nega:

Podia-se, por outro lado, pensar numa generalização, visto que a pronúncia de Portugal, como se sabe, profere como abertas, vogais pretônicas decorrentes de crases antigas. (...) Contudo devemos dizer que o fenômeno é tão enraizado, tão popular e generalizado, que nos parece tal hipótese muito pouco provável (SILVA NETO, 1963, p. 189-190).

Ao estudar a variedade nordestina, Marroquim (1934, p. 51-52) conclui que esse traço peculiar não decorre de influência tupi. Para ele, "a língua portuguesa sujeita a influências evolutivas particulares, assume aspectos prosódicos próprios em cada região". Nesse trecho, a intenção de Marroquim é contrariar a opinião de Nascentes, de que o tupi teria favorecido a pronúncia aberta. Ao verificar o texto de Nascentes (1965), entretanto, percebemos que o propósito do autor ao referir-se à interferência da língua indígena não está restrito à variedade nordestina:

No Brasil a língua portuguesa pôs-se em contato com o tupi, idioma de um dos nossos grandes troncos indígenas, e mais tarde com as línguas faladas pelos escravos africanos introduzidos pelos portugueses. Daí resultou para ela uma modalidade especial graças às alterações fonéticas, morfológicas e sintáticas e aos acréscimos do vocabulário (NASCENTES,1965, p. 177).

Para Nascentes (1953, p. 19), o aspecto histórico pode fornecer pistas mais razoáveis para esse desenvolvimento. O autor leva em conta o modo como o país foi povoado. Os colonos portugueses não ocuparam o território brasileiro de forma homogênea, mas formando centros populacionais no litoral. Os principais foram: São Paulo, Pernambuco e Bahia, que se constituíram, além de centros urbanos, irradiadores da fala portuguesa para o interior. Assim, São Paulo, por meio dos bandeirantes, desbravou Minas Gerais, Goiás, Mato Grosso, Paraná,
Revista Letras,

Curitiba, UFPR, n. 96, pp.104-131, jul./dez. 2017. ISSN 2236-0999 (versão eletrônica) 
Santa Catarina e Rio Grande do Sul. Os pernambucanos desbravaram a Paraíba, o Rio Grande do Norte, o Ceará, Alagoas e, por intermédio desses Estados, o Acre. Bahia influenciou a região que inclui o Sergipe e o norte do Espírito Santo. A consequência natural dessa organização foi o surgimento de regiões distintas, explica Nascentes (1953, p. 19): "As vias de comunicação, as relações comerciais e intelectuais, certas vicissitudes históricas ligaram diversas partes do vasto território, constituindo regiões perfeitamente caracterizadas".

Tendo em mente as relações e contatos desses três grupos irradiadores da fala portuguesa, Nascentes (1953, p. 24) elaborou o mapa dos subfalares do PB, fundamentando-se numa observação panorâmica da fala brasileira: "Hoje que já realizei o meu ardente desejo de percorrer todo o Brasil, do Oiapoc ao Xuí, de Recife a Cuiabá, fiz nova divisão que não considero nem posso considerar definitiva, mas sim um tanto próxima da verdade”. O autor verificou a existência de dois grandes grupos: o norte e o sul, cujas características são "a cadência e a existência de pretônicas abertas em vocábulos que não sejam diminutivos nem advérbios em mente" (1953, p. 25). O grupo norte é subdividido em dois outros subfalares: o amazônico e o nordestino; enquanto o grupo sul é subdividido em outros quatro: o baiano, o fluminense, o mineiro e o sulista. As isoglossas traçadas por Nascentes não coincidem com os limites entre regiões e Estados brasileiros; por vezes estão próximos, mas nem sempre são os mesmos.

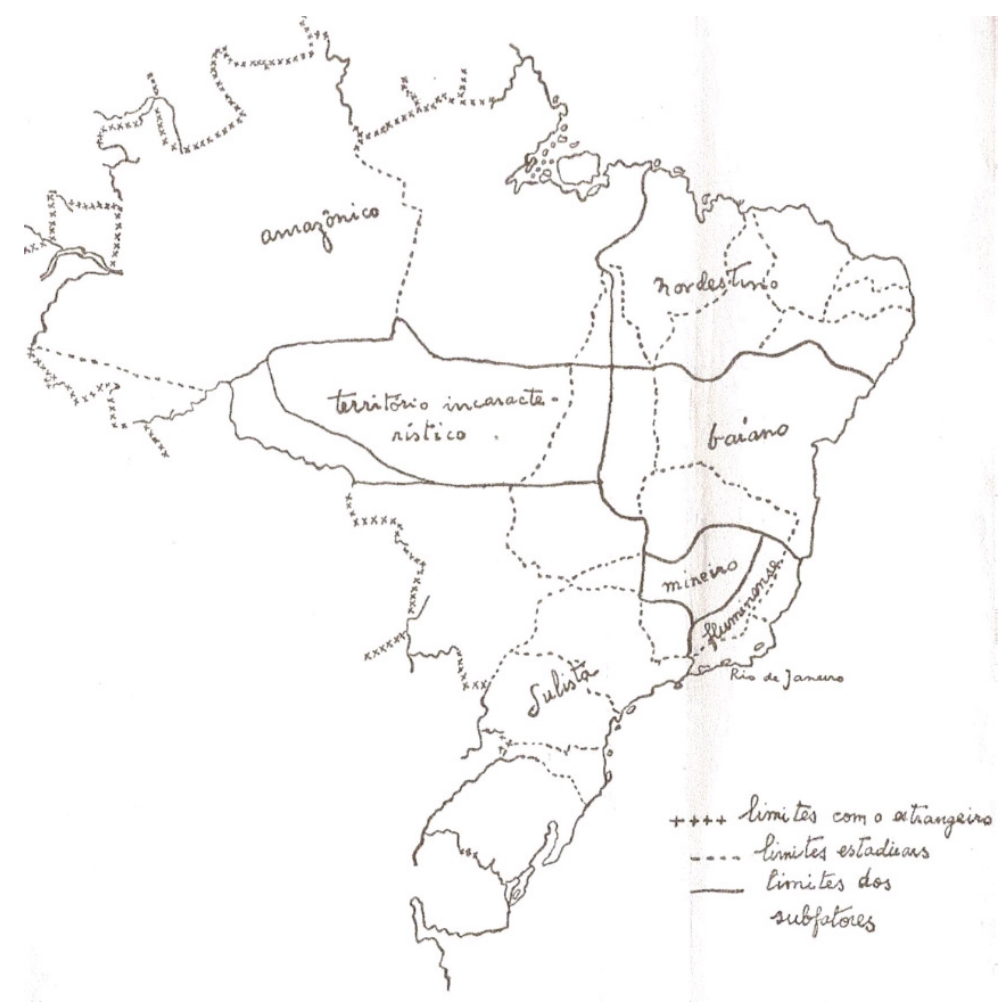

Mapa 1: Isoglossas do Português Brasileiro segundo Antenor Nascentes Fonte: Nascentes (1953, p. 18)

Enfim, embora não nos seja possível detectar quais os aspectos determinantes para a configuração do $\mathrm{PB}$ em dois grandes grupos, o fato 
G. S. Graebin A Pronúncia das

Vogais Médias no Português

Europen e

no Português

Brasileiro: um estudo diacrônico é que a distinção fonética e prosódica entre norte e sul, conforme observou Nascentes, é uma realidade inequívoca para qualquer brasileiro e problematiza, uma vez mais, a formação de uma koiné válida para todos os falantes de PB. Todas as hipóteses para essa configuração ainda precisam ser melhor apuradas pela pesquisa linguística, tais como: (i) a generalização, na região Nordeste, da pronúncia aberta do PE; (ii) a influência de diferentes variedades portuguesas nos três centros irradiadores da fala portuguesa; (iii) a interferência linguística de negros e indígenas; (iv) a consequência de evoluções históricas regionais.

\section{Português Brasileiro atual}

O apanhado histórico da pronúncia das vogais médias em posição pretônica, desde as primeiras mudanças ocorridas do latim para o PE até o PB atual, demonstra que o sistema vocálico da língua portuguesa, especialmente no que diz respeito às vogais médias, é bastante complexo. Como o linguista Câmara Jr. (2007) já observara,

a realidade da língua oral é muito mais complexa do que dá a entender o uso aparentemente simples e regular das cinco letras latinas vogais na escrita. O que há são 7 fonemas vocálicos multiplicados em muitos alofones. (CÂMARA JR., 2007, p. 39)

Em posição tônica são encontradas tanto as médias-fechadas /e/ e /o/ quanto as médias-abertas /E/ e / $/$ /, formando oposições do tipo /'forma/ - /'forma/, /'pelu/ - /'pelu/. Em posição pretônica, porém, as oposições não ocorrem, ou seja, não é possível encontrar pares mínimos entre os sons [e $\varepsilon$ ] ou [o o]. Palavras que, na grafia, terminam com $e$ e $o$ são pronunciadas, majoritariamente, com [I] e [v] e não com [e] e [o]. O quadro comparativo a seguir apresenta a gradativa diminuição do número de fonemas nas posições tônica, pretônica e postônica, com 7, 5 e 3 fonemas vocálicos respectivamente:

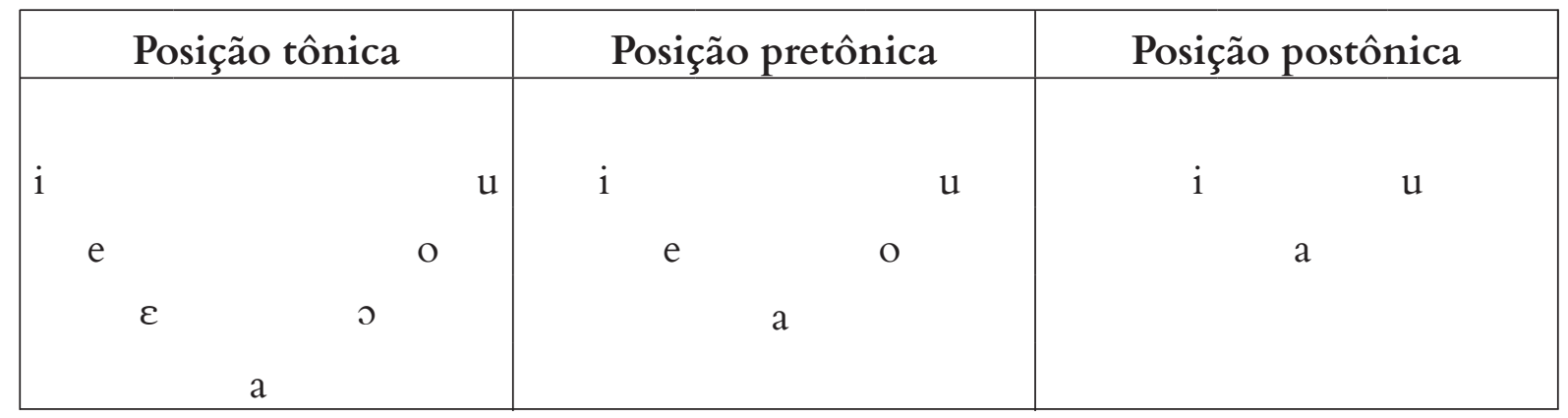

Quadro 8: Quadro fonológico comparativo das vogais do português brasileiro - posição tônica, pretônica e postônica
Revista Letras,

Curitiba, UFPR, n. 96, pp.104-131, jul./dez. 2017. ISSN 2236-0999 (versão eletrônica) 
A observação do quadro comparativo permite perceber que as diferenças se concentram essencialmente entre as vogais médias. Segundo Wetzels (1992), esse é um processo de mudança sonora comum às línguas românicas:

(...) in $\mathrm{BP}$, as in all the Romance languages, the opposition between upper and lower mid vowels is, in a sense, less basic than the one between high and low vowels. (...) Indeed, both the historical evolution of the Romance languages and synchronic alternations provide strong evidence for the fact that the distinction between mid vowels is the first to be abandoned, if neutralization occurs. ${ }^{12}$ (WETZELS, 1992, p. 23)

Câmara Jr. (1953, p. 76) explica que "basta a ausência de tonicidade para anular as oposições distintivas entre / $\varepsilon /$ e /e/, de um lado, e, de outro lado, entre / / e /o/, com a fixação do segundo elemento de cada par na pronúncia do Rio de Janeiro". O autor destaca que, em posição pretônica, a neutralização não ocorre entre as vogais médias /e o/ e altas /i u/, por dois motivos: (i) em caso de dúvida quanto ao sentido da palavra, a oposição pode ser recuperada, como nos pares soar (fazer som) e suar (verter suor), comprido (longo) e cumprido (executado), pear (embaraçar) e piar (soltar pios); (ii) no processo morfológico de derivação, a pronúncia média-fechada tende a se manter, aproximando-se da forma primitiva. Câmara Jr. (2007, p. 45) denomina esse tipo de variação de "debordamento" ou "cumulação".

No Rio de Janeiro, a variação a que as vogais médias-fechadas estão submetidas em posição pretônica se dá, sobretudo, pela harmonização ou assimilação do traço [+ alto] da vogal seguinte. A efetivação da harmonização depende, segundo Câmara Jr., de dois fatores extremamente ligados entre si: (i) a fala não cuidada, ou seja, o estilo informal (2007, p. 44): "No registro informal do dialeto carioca, as oposições entre /o/ e /u/, de um lado, e, de outro lado, entre /e/ e /i/ ficam prejudicadas pela tendência a harmonizar a altura da vogal pretônica com a da vogal tônica quando esta é átona"; e (ii) itens lexicais frequentes (1953, p. 80): "os vocábulos muito usuais, fixam-se, em regra, sob a forma alterada pela harmonização, em virtude de aparecerem preponderantemente na pronúncia coloquial frouxa e na língua popular".

Assim, em posição pretônica, as vogais médias fechadas e abertas neutralizam-se; não há, portanto, pares mínimos entre esses dois fonemas

12 Tradução nossa: "em PB, como em todas as línguas românicas, a oposição entre médias fechadas e abertas é, em certo sentido, menos básica do que entre vogais altas e baixas (...) De fato, tanto a evolução histórica das línguas românicas quanto as alterações sincrônicas provêm forte evidência para o fato de que a distinção entre as vogais médias é a primeira a ser abandonada, se a neutralização ocorre". 
G. S. Graebin A Pronúncia das

Vogais Médias no Português

Europeu e

no Português

Brasileiro: um estudo diacrônico nessa posição. As possibilidades fonéticas, contudo, admitem a variação entre as formas $[\mathrm{e}] \sim[\varepsilon]$ e $[\mathrm{o}] \sim[\mathrm{o}]$, assim como a variação entre $[\mathrm{e}] \sim[\mathrm{i}] \mathrm{e}[\mathrm{o}] \sim$ [u]. Na maioria dos subfalares do Sul, para manter a terminologia usada por Nascentes (1953) as formas médias-abertas [ $\varepsilon$ ] e [o] ficam restritas a um pequeno número de vocábulos, aqueles formados pelo processo de derivação em -inho e -mente, sufixos que produzem diminutivos e advérbios. No subfalar baiano e nos subfalares do Norte, não considerados no estudo de Câmara Jr. a respeito da fonologia do $\mathrm{PB}$, formas médias-abertas, porém, são muito mais produtivas. $\mathrm{O}$ gráfico seguinte, formulado por Leite \& Callou (2004, p. 40) a partir de dados de fala de cinco capitais brasileiras, mostra que nas duas capitais nordestinas, Recife e Salvador, há um alto índice de vogais médias-abertas em posição pretônica. Em Recife, $47 \%$ das ocorrências foram com essa forma e, em Salvador, o percentual sobe para $60 \%$. No Rio de Janeiro, o uso dessa variante teve um percentual de 5\%; nas capitais de São Paulo e do Rio Grande do Sul não foi registrada nenhuma ocorrência de vogal média-aberta.

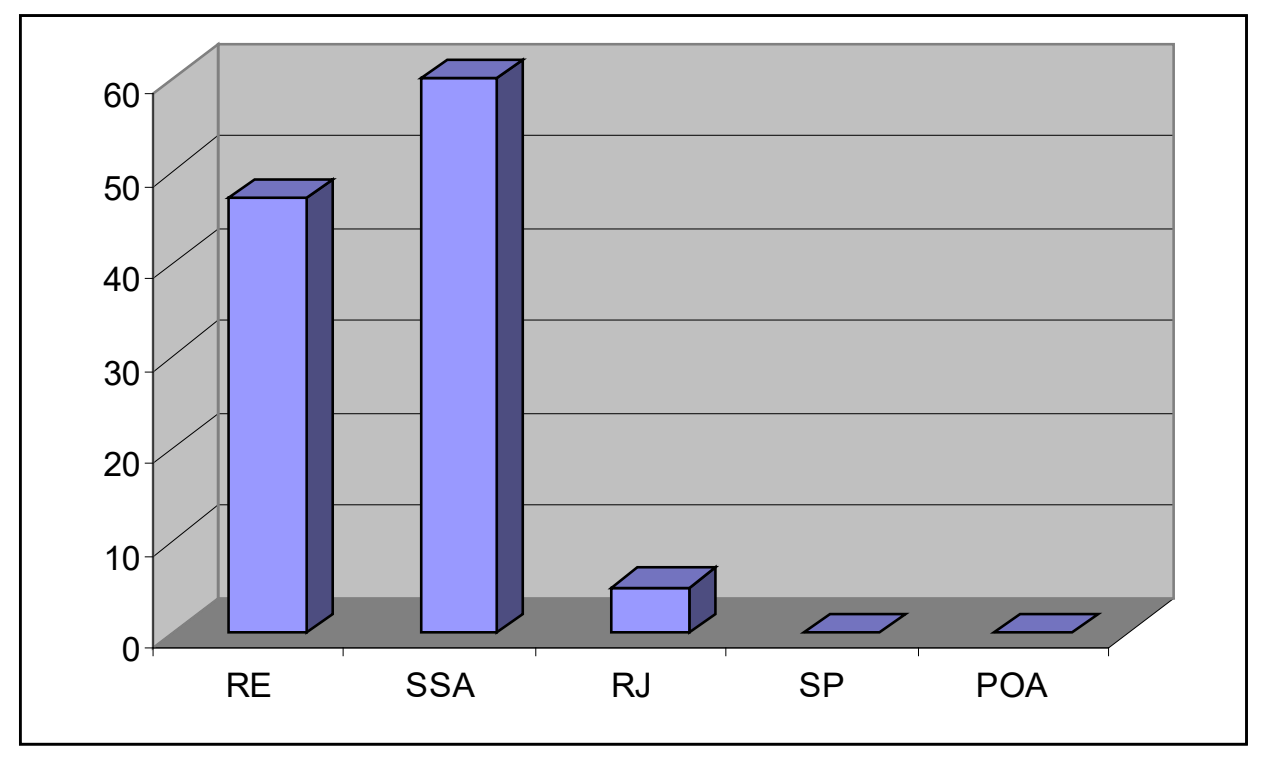

Gráfico 1: Percentuais de abaixamento das vogais médias pretônicas em Recife, Salvador, Rio de Janeiro, São Paulo e Porto Alegre

Fonte: Leite \& Callou (2004, p. 40)

O fenômeno de elevação das vogais médias $[\mathrm{e}] \sim[\mathrm{i}]$ e [o] [u] é observado em todo o território brasileiro, em maior ou menor medida. Já o processo de abaixamento $[\mathrm{e}] \sim[\varepsilon]$ e $[\mathrm{o}] \sim[\mathrm{o}]$, aparece predominantemente nos subfalares do Norte. ${ }^{13}$

As primeiras pistas para o processo de abaixamento das vogais médias, na região Nordeste, encontram-se no trabalho de Marroquim, A língua do Nordeste, publicado em 1934. O autor procura descrever a variação entre a pronúncia média-aberta $[\varepsilon, o]$, média-fechada $[e, o]$ e alta $[i, u]$ na fala de Pernambuco e

13 Alguns casos de abaixamento encontrados por Callou; Leite \& Coutinho (1991: 75), no Rio de Janeiro, todos em ambiente favorável à harmonização vocálica foram: entròsamento, rèlações, dòméstico, tòmava, nègócio.
Revista Letras,

Curitiba, UFPR, n. 96, pp.104-131, jul./dez. 2017. ISSN 2236-0999 (versão eletrônica) 
Alagoas, ressaltando que ela ocorre indistintamente em todas as classes sociais. Para a série anterior, Marroquim (1934, p. 51) registra o abaixamento em :

- posição inicial absoluta: èlétrico, èlègância, èloqüente, èquiparar, èpopéa, èquilíbrio, èpiceno, èquivocar, èvasão, èvaporar, èvocar, èvangelho;

- em posição medial: lèvar, navègar, elèvar, dèzembro, sètembro, sèzão, pècado, pèdal, vèthaco.

A pronúncia média-aberta $[\varepsilon]$ é encontrada até mesmo em palavras originalmente com /i/ (1934, p. 55): cèrconstança, dèfamá, dèfêrença, dèploma, lècença. Outras palavras apresentam a troca de /i/ por [e] dêreito, rebêra, premêro. Marroquim (1934, p. 55) destaca que "muitas palavras que têm esta pronúncia são oriundas do português do século XVI e conservadas integralmente no dialeto".

A série posterior, segundo Marroquim (1934, p. 55), apresenta um leque maior de possibilidades: "O $o$ tem o som de ó, ô, e $u$. Há uma grande indecisão entre essas três formas, não sendo possível determinar uma direção segura para a mudança dialetal. Dentro de cada regra formulada há, quase sempre, inúmeras exceções”. O autor registra ocorrências com o timbre aberto [0] em:

- posição inicial absoluta: Òliveira, òfício, òceano, òbrigação, òráculo, òpilação, òrador, òrdenar, òrgulho, òrnamentado;

- Seguido de $l$ ou $r$ com que forme sílaba: sòrdado, jòrnal, pòrtador, tòrmento, tòrrencial;

- Infinitivos da primeira conjugação: chòrar, implòrar, còbrar, amòjar, bròcar, tòcar, tòpar, ròlar. Exceções são mulhar e butar.

Em palavras começadas com $/ \mathrm{m} /$ as três variantes são possíveis (MARROQUIM, 1934, p. 56):

- Com média-fechada [o]: morrer, morder, moleza;

- Com média-aberta $[\square]$ : mòrgado, mòrdaça, mòrdomo, mòrmaço, mòrtalha, mòlenga;

- Com alta [u]: murcego, murrinha, muldura.

Verbos da segunda conjugação mantêm o timbre fechado [o] e os da terceira conjugação sofrem elevação, pronunciados como [u]. Com o ditongo ou (1934, p. 65) ocorre monotongação, em ôtro, lôco, pôço, frôxo, môco, ôro; elevação com o verbo uvir e derivados: uvido, uvinte; abaixamento em Lòrenço, estòrar, ròbar, pòcar, afròxar. Marroquim (1934, p. 65) ressalta que "na língua culta há 
G. S. Graebin A Pronúncia das

Vogais Médias no Português

Europeu e

no Português

Brasileiro: um estudo diacrônico também verbos em que houve igual transformação: apòsentar e apòquentar vem de pouso e pouco".

Na Paraíba, o estudo das formas encontradas no Atlas linguístico da Paraíba (ARAGÃO; MENEZES, 1984, p. 46,47) concluiu que "o modelo de realização mais frequente e de distribuição regular na Paraíba é [E] [0]”, tanto em posição inicial de sílaba - èliti, èducar, òração -, como em posição medial - tèlèvisão, còrcunda, gòiaba.

A exposição de resultados de pesquisas conduzidas em várias partes do país mostra, portanto, que as relações das variantes [i] [e] [e] para o fonema /e/ e de [u] [o] [o] para o fonema /o/, na fala em uso, são bastante complexas. Diante desse quadro, verifica-se a insuficiência de uma regra única que abranja todos os tipos de variações existentes em posição pretônica no PB. Assim, temos por um lado um quadro fonológico, constituído de 5 fonemas vocálicos, decorrente da neutralização, e por outro, um quadro fonético com 7 vogais, que representa as possibilidades de seleção exercida pelos falantes de $\mathrm{PB}$, com a seguinte tendência: falantes de variedades localizadas mais ao sul do país se atêm mais às variantes médias-fechadas [e o] e altas [i u], enquanto falantes de variedades mais ao norte do país fazem uso das três variantes: médias-fechadas [e o], altas [i u] e médiasabertas $[\varepsilon \supset]$.

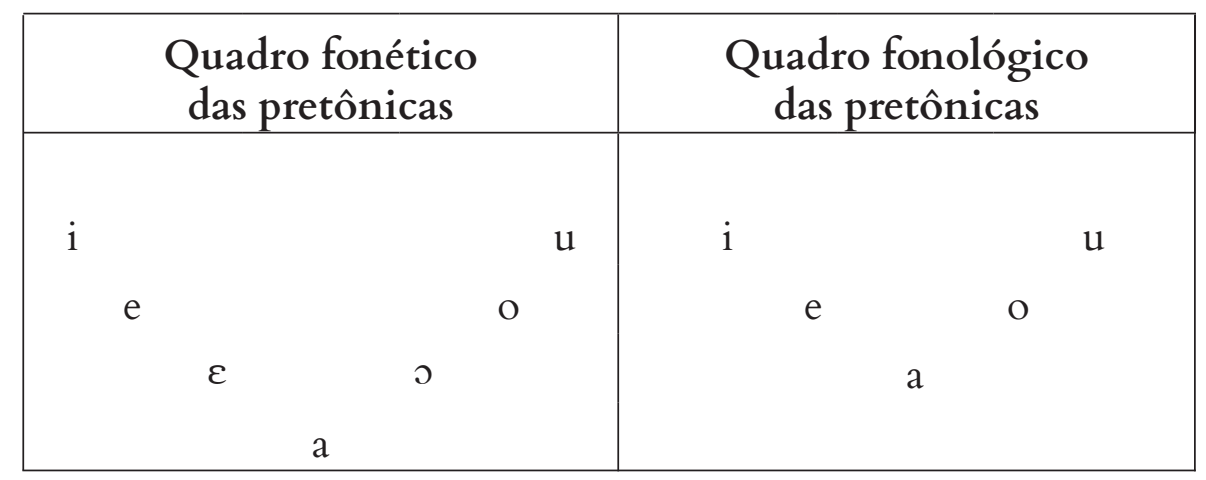

Quadro 9: Comparação entre os quadros fonético e fonológico das vogais pretônicas do português brasileiro

\section{Considerações finais}

No que diz respeito à pronúncia das vogais médias, $\mathrm{O}$ PB manteve as tendências em andamento na língua portuguesa. A análise dos dados fornecidos por gramáticos e dialetólogos portugueses atesta que a elevação das vogais /e/ e /o/ ocorria já no século XVI como uma regrava variável de assimilação. Além disso, em ambientes fonéticos específicos como o da vogal /e/ em início de palavra seguido por /S/ou nasal, a elevação era a opção mais utilizada (ixame
Revista Letras,

Curitiba, UFPR, n. 96, pp.104-131, jul./dez. 2017. ISSN 2236-0999 (versão eletrônica) 
para exame, intrei para entrei). Tais pronúncias não foram abandonadas no PB; pelo contrário, como algo já enraizado na língua, disseminaram-se por todas as variedades faladas no país.

Da mesma maneira, o fenômeno do abaixamento das vogais pretônicas não nasceu no português falado na colônia, mas veio na bagagem dos falantes de Portugal. Pronúncias realizadas atualmente no Brasil com as médias-abertas [ع] e [๖], em sílabas travadas, como vèrgonha, èrvilha, òrgulho, hòspital, já eram encontradas no PE no século XVI e permaneceram na língua, sendo descritas por Gonçalves Viana (1883) e Vasconcelos (1901) no final do século XIX. No Brasil, o abaixamento das médias não se tornou tão abrangente como a elevação. Restringiu-se, principalmente, à região Nordeste do país e, para o dialetólogo Nascentes (1953), foi o fator-chave para dividir o país em dois grandes grupos linguísticos: os falares do norte e os falares do sul.

É importante ressaltar que a análise dos dados levantados revela que tanto a elevação quanto o abaixamento das vogais médias pretônicas sofrem a influência de fatores sociais, geográficos e culturais sobre a língua, seja a falada em Portugal, seja a falada no Brasil. Os fenômenos são variáveis e nem sempre ambientes que, a princípio, parecem ser favoráveis para a elevação ou para o abaixamento apresentam a pronúncia esperada, e vice-versa. Enquanto em alguns lugares do Brasil a pronúncia para bolacha é bôlacha, em outros é bulacha, mas nunca bòlacha. Para vestido é possível encontrar a pronúncia vistido, mas não vèstido; para vestibular, é possível encontrar vèstibular, mas não vistibular.

Por fim, o PB não passou pelo processo de redução e aceleração rítmica ocorridos no PE no século XVIII, o qual afetou profundamente a pronúncia das vogais pretônicas. Desde então, a pronúncia do PB e do PE tomou rumos distintos, o que pode dar a impressão de serem duas línguas com histórias completamente diferentes. Este estudo diacrônico mostra, no entanto, que a língua falada pelos brasileiros é o bom e velho português. 


\section{G. S. Graebin}

A Pronúncia das

Vogais Médias

no Português

Europeu e

no Português

Brasileiro: um estudo diacrônico

\section{Referências Bibliográficas}

ALMEIDA, Manoel Mourivaldo Santiga. Ecos fonético-fonológicos no falar cuiabano. In: MANOEL ALMEIDA, Maria Inês Cox (Org.) Vozes cuiabanas: estudos linguísticos em Mato Grosso. Cuiabá: Cathedral, 2005. p. 69-93.

AMARAL, Amadeu. O dialeto caipira. São Paulo: Casa editora "O livro”, 1920.

ARAGÃO, Maria do Socorro Silva de; MENEZES, Cleuza Palmeira Bezerra de. Atlas linguístico da Paraíba: análise das formas e estruturas linguísticas encontradas. vol. 2. Brasília: Universidade Federal da Paraíba/CNPq, Coordenação Editorial, 1984.

BARBOSA, Jorge Morais. Etudes de phonologie portugaise. Lisboa: Junta de investigações do Ultramar, 1965.

BARROS, João de. Gramática da língua portuguesa. Lisboa: Publicações da Faculdade de Letras da Universidade de Lisboa, 1971 [1540].

CALLOU, Dinah; LEITE, Yonne; COUTINHO, Lilian. Elevação e abaixamento das vogais pretônicas no dialeto do Rio de Janeiro. Organon Revista do Instituto de Letras da Universidade Federal do Rio Grande do Sul, Porto Alegre, v.5, n.18, 1991, p.71-78.

CAMARA JUNIOR, Joaquim Mattoso. Para o estudo da fonêmica portuguesa. Rio de Janeiro: Simões, 1953.

. Estrutura da língua portuguesa. 39. ed. Petrópolis: Vozes, 2007.

CASTILHO, Ataliba T. de. O Português do Brasil. In: ILARI, Rodolfo. Linguística românica. 3. ed. São Paulo: Ática, 2006. p. 237-269.

ELIA, Silvio. Ensaios de filologia. Rio de Janeiro: Acadêmica, 1963.

FERREIRA, Carlota da Silveira. Atlas linguístico de Sergipe. Salvador: Universidade Federal da Bahia, 1987.

GONÇALVES VIANA, Aniceto R. Essai de phonétique et de phonologie de la langue portugaise, d'après le dialecte actuel de Lisbonne (1883). In:

Estudos de fonética portuguesa. Lisboa: Imprensa Nacional, 1973.

HONÓRIO RODRIGUES, José. A Vitória da Língua Portuguesa no Brasil Colonial. Humanidades, v.1, n. 4, p. 21-41, 1983.

LEITE, Yonne; CALLOU, Dinah. Como falam os brasileiros. 2.ed. Rio de Janeiro: Jorge Zahar, 2004.

LIÃO, Duarte Nunes do. Origem e ortografia da lingua portuguesa. Lisboa: Tipografia do Panorama, 1864 [1576].
Revista Letras,

Curitiba, UFPR,

n. 96, pp.104-131,

jul./dez. 2017.

ISSN 2236-0999

(versão eletrônica) 
MATTOS E SILVA, Rosa Virgínia. Português brasileiro: raízes e trajetórias. Ciência hoje - conquista e colonização, v. 5, n. 86, p.76-81, 1992.

MARROQUim, Mário. A língua do Nordeste. São Paulo: Companhia Editora Nacional, 1934.

MONTE CARMELO, Luis. Compendio de Ortographia. Lisboa: Officina de Antonio Rodrigues Galhardo, 1767.

NARO, Anthony Julius. Estudos diacrônicos. Petrópolis: Vozes, 1973.

NASCENTES, Antenor. O linguajar carioca. 2.ed. Rio de Janeiro: Simões, 1953. O idioma nacional. 5.ed. Rio de Janeiro: Acadêmica, 1965.

NUNES, José Joaquim. Compêndio de Gramática Histórica Portuguesa. 6.ed. Lisboa: Livraria Clássica, 1960.

OLIVEIRA, Fernão de. Grammatica da linguagem portuguesa. 3.ed. Lisboa: Edição de José Fernandes Jr., 1936 [1536].

PAES, Elpídio Ferreira. Alguns aspectos da fonética sul-riograndense. Anais do Primeiros Congresso de Lingua Nacional Cantada. São Paulo, Departamento de Cultura, 1938.

RODRIGUES, Aryon D. As línguas gerais sul-americanas. Papia, v. 4, n. 2, p. 6-18, 1996.

Segunda visitação do Santo Ofício às partes do Brasil, separata dos Anais do Museu Paulista, t. XVII, São Paulo, 1963.

SILVA, Myriam Barbosa da. As pretônicas no falar baiano: a variedade culta de Salvador. Tese (Doutorado em Língua Portuguesa) -Faculdade de Letras, UFRJ, Rio de Janeiro, 1989.

SILVA NETO, Serafim da. Introdução ao estudo da lingua portuguesa no Brasil. 2.ed. Rio de Janeiro: Instituto Nacional do Livro, 1963.

. História da língua portuguesa. 3.ed. Rio de Janeiro: Presença, 1979.

SOARES BARBOSA, Jerônimo. Gramática filosófica da língua portuguesa. Lisboa: Academia Real das Sciencias, 1822.

TEIXEIRA, José Aparecida. Estudos de dialectologia portuguesa. Linguagem de Goiás. São Paulo: Anchieta, 1944.

TEYSSIER, Paul. História da Lingua Portuguesa. Trad. Celso Cunha. São Paulo: Martins Fontes, 2004.

VASCONCELOS, José Leite de. Esquisse d'une dialectologie portugaise. Paris: Aillaud, 1901. 
G. S. Graebin A Pronúncia das

Vogais Médias no Português

Europeu e no Português Brasileiro: um estudo diacrônico
Gonçalves Viana. Apontamentos para a sua biografia. In: GONÇALVES VIANA, Aniceto R. Estudos de fonética portuguesa. Lisboa: Imprensa Nacional, 1973. p. 21-37.

WETZELS, W. Leo. Mid vowel neutralization in brazilian portuguese. Caderno de estudos linguísticos, Campinas, v. 23, jul.-dez. p.19-55, 1992.

Submetido em: 02-02-2017

Aceito em: 26-05-2017 